\title{
A new leafhopper genus with two new species related to Masiripius Dlabola, 1981 (Hemiptera, Deltocephalinae, Cicadellidae, Opsiini)
}

\author{
Saad A. EL-SONBATI ${ }^{1, *}$, Michael R. WILSON ${ }^{2} \&$ Hathal M. AL DHAFER $^{3}$ \\ ${ }^{1,3}$ King Saud University, Plant Protection Department, College of Food and Agriculture Science, \\ King Saud University Museum of Arthropods, P.O. Box 2460, Riyadh 11451, Saudi Arabia. \\ ${ }^{2}$ Department of Natural Sciences, National Museum of Wales, \\ Cardiff CF10 3NP, Wales, U.K. \\ *Corresponding author: ssonbati@ksu.edu.sa \\ ${ }^{2}$ Email: mike.wilson@museumwales.ac.uk \\ ${ }^{3}$ Email: hdhafer@ksu.edu.sa \\ ${ }^{1}$ urn:1sid:zoobank.org:author:E6A717FA-64D6-441D-AB29-070C8707D7D2 \\ ${ }^{2}$ urn:Isid:zoobank.org:author:0F3D8D63-F677-4A68-9BEA-005FC429108B \\ ${ }^{3}$ urn:1sid:zoobank.org:author:6117A7D3-26AF-478F-BFE7-1C4E1D3F3C68
}

\begin{abstract}
The genus Oshaibahus El-Sonbati \& Wilson gen. nov. is described with the type species Platymetopius zizyphi Bergevin, 1922. Two new species, O. kadiae El-Sonbati \& Wilson gen. et sp. nov. from Sudan and O. linnavuorii El-Sonbati \& Wilson gen. et sp. nov. from Iraq are described, and a new combination, Oshaibahus zizyphi (Bergevin, 1922) gen. et comb. nov. is proposed. The genus Masiripius Dlabola, 1981 (type species: Mahalana lugubris Distant, 1918) is redefined. An illustrated key to genera of the subtribe Opsiina and a key to species of Oshaibahus gen. nov. are presented to facilitate identification.
\end{abstract}

Keywords. Hemiptera, Auchenorrhyncha, Cicadellidae, Deltoephalinae, Opsiini, leafhoppers.

El-Sonbati S.A., Wilson M.R. \& Al Dhafer H.M. 2017. A new leafhopper genus with two new species related to Masiripius Dlabola, 1981 (Hemiptera, Deltocephalinae, Cicadellidae, Opsiini). European Journal of Taxonomy 308: $1-24$. https://doi.org/10.5852/2017.308

\section{Introduction}

Leafhoppers are an important group of insects for their often high abundance, host plant specialization, plant disease transmission, and response to environmental disturbance (Nielson \& Knight 2000; Hollier et al. 2005; Zahniser \& Dietrich 2008; Hamilton \& Whitcomb 2010). The leafhopper tribe Opsiini is one of the most important tribes in the subfamily Deltocephalinae and species of this tribe are important vectors of viral and bacterial (phytoplasma and spiroplasma) phytopathogens (Nielson 1968; Fletcher \& Wayadande 2002; Weintraub 2007; Munyaneza et al. 2008). 
In this paper, we describe a new genus in the Opsiini-Oshaibahus El-Sonbati \& Wilson gen. nov.-and two new species: $O$. kadiae El-Sonbati \& Wilson gen. et sp. nov. from Sudan and O. linnavuorii ElSonbati \& Wilson gen. et sp. nov. from Iraq. The new genus is closely related to Masiripius Dlabola, 1981; male genitalia must be examined to distinguish between and separate the genera. The world distribution for both genera is shown in Fig. 1: Oshaibahus El-Sonbati \& Wilson gen. nov. is known from Algeria, Libya, Iraq, Sudan and the Kingdom of Saudi Arabia (Muzahimiyah in Al Khararah and Rhodet Khorim, Figs 2-3); the known distribution of Masiripius includes India, Iran, and also Oman and Qatar of the Arabian Peninsula.

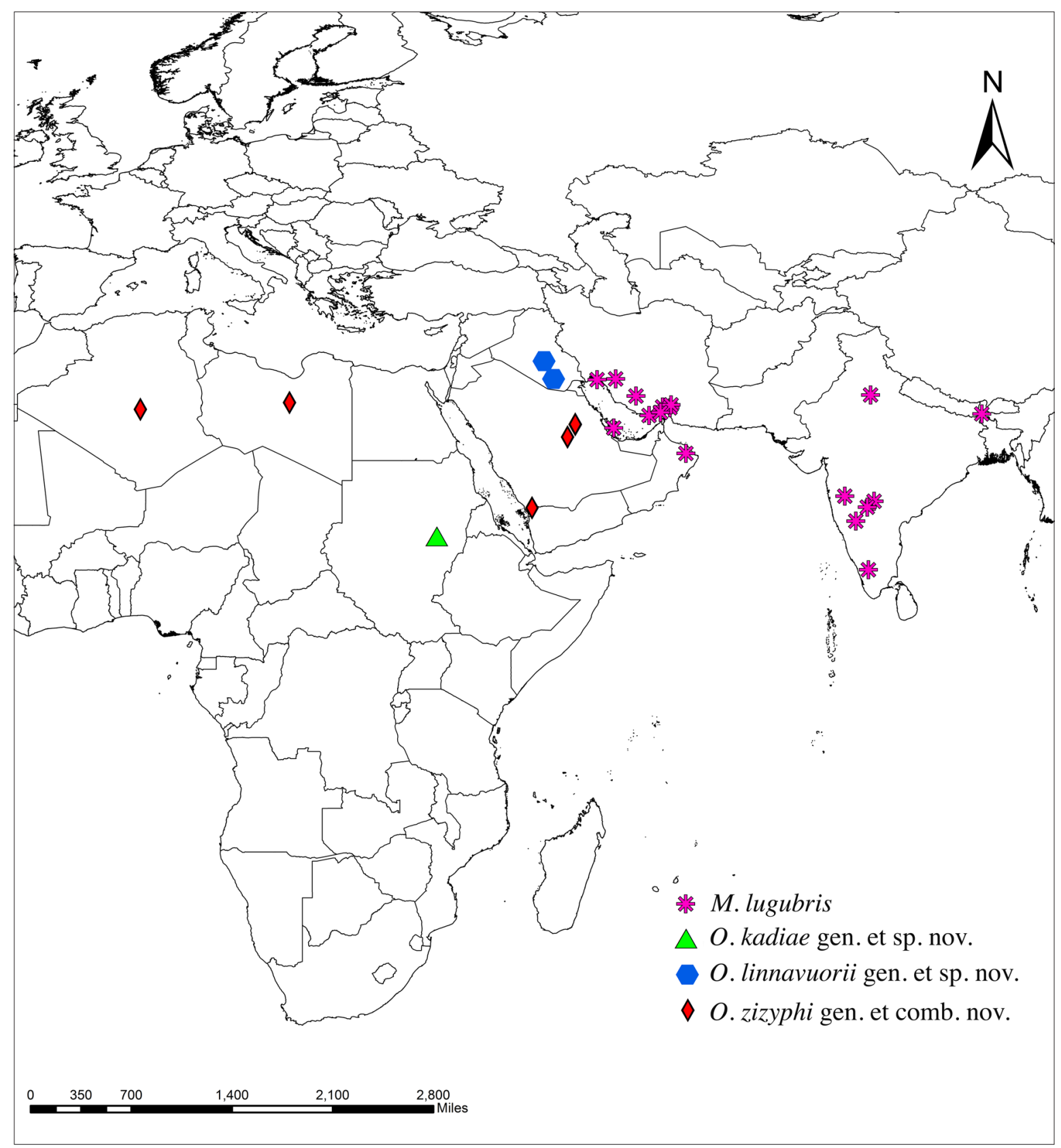

Fig. 1. World distribution of the genera Oshaibahus El-Sonbati \& Wilson gen. nov. and Masiripius Dlabola, 1981. 


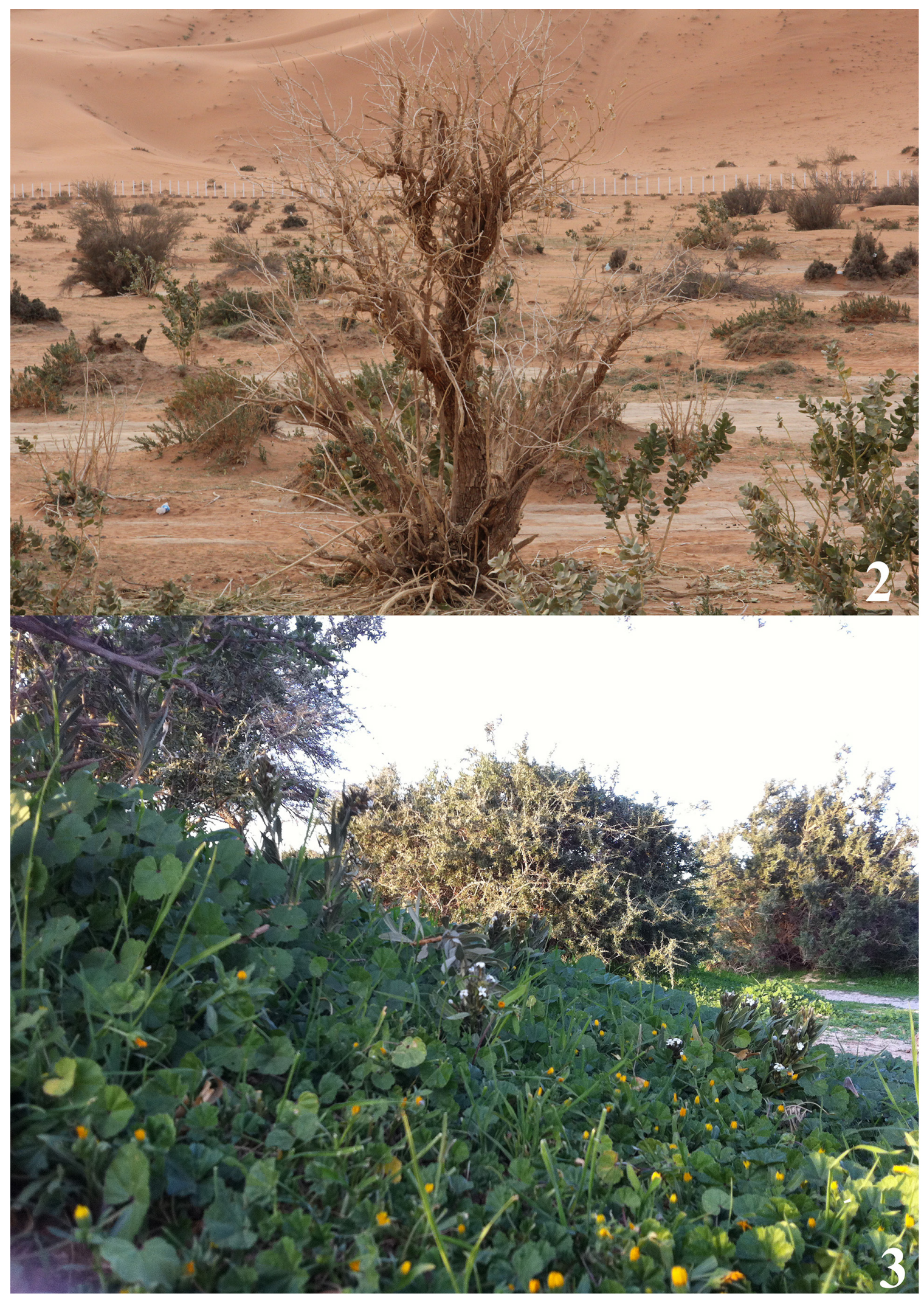

Figs 2-3. Habitats of Oshaibahus zizyphi (Bergevin, 1922) gen. et comb. nov. 2. Type locality: Muzahimiyah, Al Khararah, KSA. 3. Additional locality: Rhodet Khorim, KSA. 


\section{Material and methods}

Specimens examined are deposited in King Saud University Museum of Arthropods, College of Food and Agriculture Sciences (KSMA), King Saud University, Riyadh, Saudi Arabia; in the National Museum of Wales, Cardiff, UK (NMWC) and in the American Museum of Natural History, New York, USA (AMNH). Genitalia preparations were made by soaking the excised apex of the abdomen in hot $10 \% \mathrm{KOH}$ solution for 8-10 minutes. The apex of the abdomen was washed in distilled water and then transferred to glycerin for further dissection and examination. After examination, it was moved to fresh glycerin and stored in a micro vial pinned below the specimen. The distribution data were based on georeferencing material examined and plotted using Google Earth. The map was created using the program ArcGIS v.10.3. All specimens were examined with a Leica LABOPHOT-2 stereomicroscope, hand-drawings of the male genitalia were made with a NIKON microscope, with a drawing tube attachment. Images were taken using a Canon 70D DSLR attached to a Leica Z6 microscope. Individual source images were then stacked using Helicon Focus v.6.22 (Helicon Soft Ltd) extended depth of field software, with calibrated scale bars added using Syncroscopy Automontage v.5.4. Resultant images were saved as TIFFs (Tagged Image File Format) with LZW lossless compression at $3648 \times 2432$ pixel dimension. Morphological terminology follows Dietrich (2005). Measurements are in millimetres (mm).

This work was part of a M.Sc. degree program by the first author at King Saud University completed under the supervision of the second author at National Museum of Wales, Cardiff (NMWC).

\section{Abbreviations}

Morphology

$\begin{array}{lll}\mathrm{A} 1, \mathrm{~A} 2 & & \text { claval veins } \\ \mathrm{AD} & = & \text { anterodorsal } \\ \mathrm{AM} 1 & = & \text { apical anteromedial } \\ \mathrm{AV} & = & \text { anteroventral } \\ \mathrm{PD} & = & \text { posterodorsal } \\ \mathrm{PV} & = & \text { posteroventral }\end{array}$

Country

KSA $=$ Kingdom of Saudi Arabia

\section{Institutions}

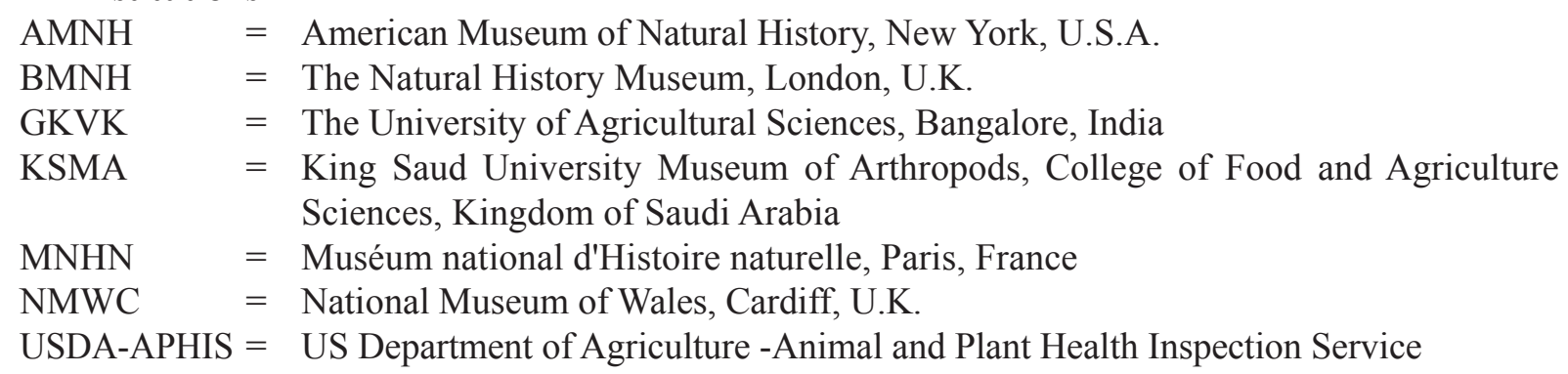




\section{Results}

\section{Key to genera of subtribe Opsiina (mostly based on males)}

1. Crown with broad red arcuate transverse band at midlength

- Crown without broad red arcuate transverse band at midlength

2. Pronotum with large median red spot; pair of sublateral longitudinal markings more or less continuous with spots on forewing clavus; scutellum with median red longitudinal stripe; forewing with three large oblong red or orange spots on claval area

- Pronotum without large median red spot; pair of sublateral longitudinal markings not continuous with forewing clavus; scutellum without median red longitudinal stripe; forewing without spots

Introrsa Dai \& Zhang, 2010

3. Pygofer with paired inner processes arising dorsally; aedeagus with paired shafts and two gonopores, aedeagal shaft with apical processes

Lampridius Distant, 1918

- Pygofer without inner process; aedeagus with one shaft and one gonopore, aedeagal shaft without apical process Paralampridius Dai, Dietrich \& Zhang, 2011

4. Crown, pronotum and scutellum with irregular red markings ...................................................... 5

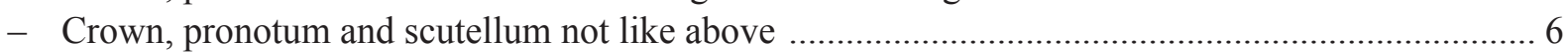

5. Abdomen with well-developed apodemes; Aedeagus without basal process

Masiripius Dlabola, 1981

- Abdomen without apodemes; Aedeagus with basal process

Oshaibahus El-Sonbati \& Wilson gen. nov.

6. Forewings, yellow, ivory or silvery white, occasionally with brown patches, particularly, wings at rest with large brown semicircular spot against midlength of commisural margin forming, and conspicuous circular spot along with that of opposite side

- Not like above

7. Aedeagus with atrium not extending ventrad of shafts

Hishimonus Ishihara, 1953

- Aedeagus with atrium extending ventrad of shafts

8. Aedeagus without ventral processes.

Naevus Knight, 1970

- Aedeagus with ventral processes

9. Aedeagal with a pair of ventral processes

Litura Knight, 1970

- Aedeagal with unpaired ventral process bifurcate in apical half .....

Libengaia Linnavuori, 1969

10. Forewing, vertex, pronotum, and scutellum with dark-brown vermiculate lines

- Forewing, vertex, pronotum, and scutellum not like above

11. Aedeagus with parallel or diverging or slightly converging branches, apices of branches with hooked process; in Pacific distribution; Pronotum and forewing without dark-brown filigranous stripes

Nesophrosyne Kirkaldy, 1907

- Aedeagus with parallel or diverging or slightly converging branches, apices of branches without hooked process; pronotum and forewing with dark-brown filigranous stripes

12. Aedeagus with parallel or diverging or slightly converging branches, apices of branches narrowly produced, neither reflexed nor hooked.

Orosius Distant, 1918 
- Aedeagus with diverging branches bent inwards at midlength. Apices of branches distinctive curved or reflexed to form distinctive tips .Paraorosius El-Sonbati \& Wilson, 2016

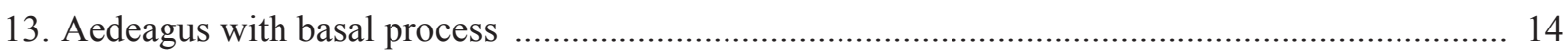

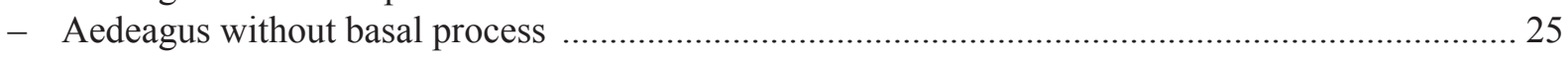

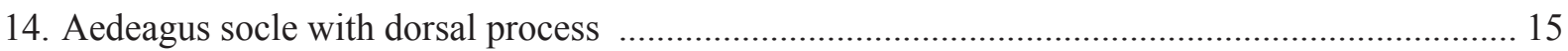

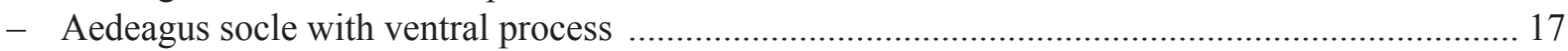

15. Crown, pronotum and scutellum with irregular red markings

Oshaibahus El-Sonbati \& Wilson gen. nov.

- Crown, pronotum and scutellum with irregular red markings.

16. Anterior margin of head never with carinae or ridge, face convex, and neither horizontal nor concave Opsius Fieber, 1866 (in part)

- Anterior margin of head angularly curved to the face with a distinct angle

Phlepsopsius Dlabola, 1979

17. Aedeagal shafts curved backwards beyond the base of aedeagus

Afrascius Linnavuori, 1969

- Aedeagal shafts not curved backwards beyond the base of aedeagus

18. Aedeagus with unpaired ventral process at base

Norva Emeljanov, 1969

- Aedeagus with pair of ventral processes at base

19. Aedeagus with 2 or 3 pairs of basal processes

Hishimonoides Ishihara, 1965

- Aedeagus with a pair of basal processes

20. Aedeagus nearly square basal socle in ventral aspect

- Aedeagus not square basal socle in ventral aspect

21. Aedeagus phragma forming a pair of large roundedly squarish plate .... Satsumanus Ishihara, 1953

- Aedeagus phragma not forming a pair of large roundedly squarish plate

Opsianus Linnavuori, 1960

22. Aedeagal with unpaired ventral process bifurcate in apical half

Libengaia Linnavuori, 1969

- Aedeagal with a pair of ventral processes

23. Forewings, yellow, ivory or silvery white, occasionally with brown patches, particularly, wings at rest with large brown semicircular spot against midlength of commisural margin forming, and conspicuous circular spot along with that of opposite side

Litura Knight, 1970

- Not like above

24. Apical part of costal margin with reflexed dark false-veilets; connective much longer than aedeagus; apophysis of style thicker Navaia Linnavuori, 1960

- Apical part of costal margin without reflexed dark false-veilets; connective much shorter than aedeagus; apophysis of style very long, slender and striaght Aladzoa Linnavuori, 1969

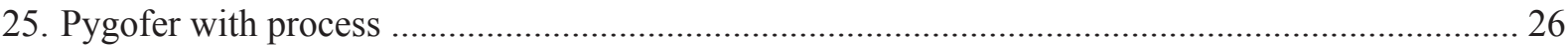

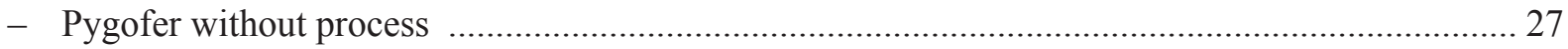

26. Crown with broad red arcuate transverse band at midlength; pronotum with large median red spot; pair of sublateral longitudinal markings more or less continuous with spots on forewing clavus; 
scutellum with median red longitudinal stripe; forewing with three large oblong red or orange spots on claval area

Lampridius Distant, 1918

- Crown, pronotum, scutellum and forewing with median yellowish longitudinal stripe flanked laterally by solid fuscous marking extending into tegmina with translucent and yellow cells

Xerophytacolus Stiller, 2012

27. Crown with broad red arcuate transverse band at midlength 28

- Crown without broad red arcuate transverse band at midlength 29

28. Pronotum with large median red spot; pair of sublateral longitudinal markings more or less continuous with spots on forewing clavus; scutellum with median red longitudinal stripe; forewing with three large oblong red or orange spots on claval area Paralampridius Dai, Dietrich \& Zhang, 2011

- Pronotum without large median red spot; pair of sublateral longitudinal markings not continuous with forewing clavus; scutellum without median red longitudinal stripe; forewing without spots

.Introrsa Dai \& Zhang, 2010

29. Crown, pronotum and scutellum with irregular red markings

Masiripius Dlabola, 1981

- Crown, pronotum and scutellum without irregular red markings

30. Pronotum and forewing without dark-brown filigranous stripes; apices of aedeagal branches with hooked process

Nesophrosyne Kirkaldy, 1907

- Pronotum and forewing with dark-brown filigranous stripes; apices of aedeagal branches without hooked process

31. Aedeagus with parallel or diverging or slightly converging branches, apices of branches narrowly produced, neither reflexed nor hooked

Orosius Distant, 1918

- Aedeagus with diverging branches bent inwards at midlength. Apices of branches distinctive curved or reflexed to form distinctive tips Paraorosius El-Sonbati \& Wilson, 2016

32. Subgenital plate without macrosetae; pygofer lobe medially with dense cluster of setae

- Subgenital plate with macrosetae; pygofer lobe medially without dense cluster of setae .............. 33

33. Forewing with dark brown border to medial spot of approximately constant width ....................... 34

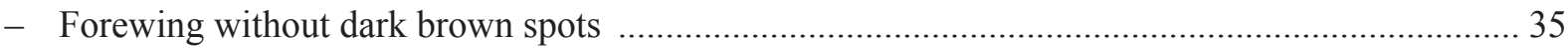

34. Aedeagus with shafts directed posteriorly at base and curving dorsally; atrium not extending ventrad of shafts

Hishimonus Ishihara, 1953

- Aedeagus with shafts directed ventroposteriorly at base and curving dorsally; atrium extending ventrad of shafts Naevus Knight, 1970

35. Aedeagus with long apical barblike processes

Kirkaldiella Osborn, 1935

- Aedeagus without long apical barblike processes

36. Subgenital plate with additional lateral plate at base; four small plates, fused basally

Alishania Vilbaste, 1969

- Subgenital plate without additional lateral plate at base

37. Vertex narrows basally, diamond shaped; compound eye are very close to each other posteriorly

Pugla Distant, 1908 
- Vertex narrows basally, diamond shaped; compound eye are very close to each other posteriorly ...

38. Anterior margin of head rounded, never with carina or ridge; with anal collar

Opsius Fieber, 1866 (in part)

- Anterior margin of head angulate, with transverse carina; without anal collar Japananus Ball, 1931

Masiripius Dlabola, 1981: 273.

Genus Masiripius Dlabola, 1981

Type species: Platymetopius zizyphi Bergevin in Bergevin \& Zanon, 1922 (misidentified type species). Viraktamath \& Anantha Murthy 1999: 44. Type species: Mahalana lugubris Distant, 1918 by subsequent designation.

Masiripius - Oman et al. 1990: 228 [Listed, Platymetopiini]. — Viraktamath \& Anantha Murthy 1999: 44 [redescribed].

\section{Diagnosis}

The combination of three characters must be examined to distinguish Masiripius from all other genera of Opsiini: (1) aedeagus without basal process with two shaft branches arising from base, (2) each shaft gradually narrowing at apex, and (3) vertex, pronotum, and scutellum with irregular red markings.

\section{Description}

Body Length. Male $3.8 \mathrm{~mm}$, female $4.2 \mathrm{~mm}$.

COLOURATION. Irregular red markings on vertex, pronotum and scutellum ground colour brownish yellow with numerous scattered brown spots and irregular reddish-brown spots.

HEAD. Head as wide as pronotum, crown slightly shorter next to eye than median length, vertex punctate, shagreen and slightly more produced in male, longer than next to eye in female, irregularly rugose, rounded to face. Frontoclypeus narrow, longer than wide, length more than $2 \times$ of width; clypeal suture straight and obsolete medially, clypellus tapered, parallel-sided, greatly produced beyond gena, apical margin sinuate, wider or subequal to lorum width; gena slightly incised; ocelli situated on anterior margin of head and close to eye; mesal margin of eye entire; lateral frontal suture reaching ocellus and directed mesad of ocelli; antennae long; antennal ledge weakly developed; antennal base situated; near middle or posteroventral (lower) corner of eye.

THORAX. Pronotum with short lateral margin, irregular blotch-like striations and produced anterad of eyes, without carinae, about $1.5 \times$ as long as scutellum; scutellum wider than long, with separate irregular blotch-like striations beyond scutellar suture.

WINGs. Forewings about $3 \times$ as long as wide, appendix restricted to anal margin, A1-A2 veins coalescing over part of their length.

LEGS. Legs yellow with brown spots. Profemur row AM with AM1, one intercalary row with more than five fine setae (or greatly reduced or absent), two dorsoapical setae, AV row with numerous stout setae, slightly short; protibia AD row with numerous macrosetae, PV row with 1-4 macrosetae; metatibia arched throughout its length, PD row with long and short macroseatae alternating or subequal in length, $\mathrm{AD}$ row with macrosetae and smaller intercalary setae, $\mathrm{AV}$ row with numerous macrosetae and extending nearly to base; metafemur setal formula $2+2+1$; metatarsomere I length equal or longer to tarsomeres II and III combined; setal areolae on legs. 
Male genitalia (Figs 11-19). Pygofer with well differentiated rows of macrosetae, without a process, long-curved ventral margin, long setulate apically; valve articulated with pygofer,with narrow point of articulation; subgenital plate with one row of macrosetae at apical margin; style bent, small, fingerlike, broadly bilobed median anterior lobe and preapical lobe well developed, tooth well-developed preapically; connective articulated with aedeagus, linear, the arms contiguous; aedeagus without basal process, aedeagal shafts arising from base.

Female Genitalia (Figs 20-22). Seventh sternite $1.5 \times$ as broad at base as long medially, narrowed posteriorly, posterior margin broadly convex with rounded lobe deeply notched in middle. Ovipositor depressed beyond pygofer apex. First valvula medially convex. Second valvula gradually tapered apically with variable serrations on dorsal surface. Numerous macrosetae on pygofer.

\section{Distribution}

Palaearctic (Oman et al. 1990).

Masiripius lugubris (Distant, 1918)

Figs 4-22

Mahalana lugubris Distant, 1918: 64.- Metcalf 1967: 2204.

Zizyphoides punctatus Rao, 1967: 239.

Masiripius zizyphi-Dlabola 1981: 274.

Masiripius lugubris - Webb \& Godoy 1993: 424. — Viraktamath \& Anantha Murthy 1999: 44.

Zizyphoides punctatus - Bhattacharyna \& Harb 1973: 391 (syn. Masiripius lugubris - Webb 1981: 50).

\section{Specimens examined}

Iran: 1 J, Masiri, S Iran, 11-12 Jun. 1973 (NMP Loc. No. 235); gender unknown, same collection data; 1 ơ, Jashak, 60 km SE Khormui, S Iran, 20-21 Apr. 1977 (NMP Loc. No. 304); 1 , 15 km NE Bandar Lengeh, S Iran, 25-26 Apr. 1977 (NMP Loc. No. 313); 2 ๙ 1977 (NMP Loc. No. 338); 1 กૈ, 1 ㅇ, 25 km W Ghasre-ghaad, SE Iran, 9-10 Apr. 1973 (NMP Loc. No. 153); 1 †, 16 km W Sabzevaran, C Iran, alt. 820 m, 19-20 May 1977 (NMP Loc. No. 338); 1 ठૈ, Hormozgan Gurband, 26 Mar.-2 Apr. 2001, R. Linnavuori leg. (AMNH); 1 q, 1 §, Hormozgan Qeshm Ramkan, 14-15 May 2002, R. Linnavuori leg. (AMNH); 2 우, Hormozgan Road, 6-12 May 2002, R. Linnavuori leg. (AMNH); 1 đ, Khuzestan Sadde-Dez, 6-7 Jun. 2005, R. \& S. Linnavuori leg. (AMNH); 1 oै, Fars, Baba Arab, 50 km SE Yahrom, 16-17 Jun. 2003, R. \& S. Linnavuori leg. (AMNH); 1 o, Fars, Farrahsband, 14-15 Jun. 2008, R. Linnavuori leg. (AMNH).

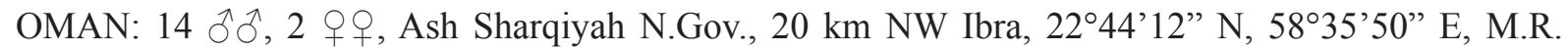
Wilson leg. (NMWC \& KSMA).

QATAR: 1 ㅇ, Doha, Al Rayyan, 27 Apr. 2014, 25¹8’0” N, 51¹9’47” E, M.R. Wilson leg. (NMWC).

\section{Description}

See genus Masiripius.

\section{Distribution}

India (Metcalf 1967), Iran (Dlabola 1981), Oman and Qatar (present study). 


\section{Genus Oshaibahus El-Sonbati \& Wilson gen. nov. urn:1sid:zoobank.org:act:F3FA5987-C661-4D25-9CCD-E5F1467ACFFE}

Figs $23-72$

Type species: Platymetopius zizyphi Bergevin in Bergevin \& Zanon, 1922.

\section{Diagnosis}

Oshaibahus gen. nov. is externally similar to Masiripius (except $O$. kadiae gen. et sp. nov.) as both genera have irregular red markings on vertex, pronotum, and scutellum. These markings also occur in the opsiine genera, Lampridius Distant, 1918, Paralampridius Dai, Dietrich \& Zhang, 2011 and Introrsa Dai \& Zhang, 2010. Both Lampridius and Paralampridius can be easily distinguished externally from Oshaibahus gen. nov. and Masiripius by the vertex having a broad red arcuate transverse band at midlength, pronotum with large median red spot, pair of sublateral longitudinal markings approximately continuous with spots on forewing clavus, scutellum with median red longitudinal stripe; forewing with three large oblong red or orange spots on claval area. Introrsa can be distinguished by a distinctive pair of similar black spots at apex of crown, transverse orange convex fascia at anterior margin; pronotum with six orange longitudinal lines on posterior portion, and scutellum with black spot at apex.

The separation and distinctiveness of Masiripius from Oshaibahus gen. nov. is based on the basal process, apical shaft branches of the aedeagus and apodemes. In Masiripius, the aedeagus lacks a basal process, the shafts are relatively straight, narrowing at the apex. Additionally, the abdomen has welldeveloped apodemes. In Oshaibahus gen. nov., the aedeagus bears a basal process branching from base curving preapically with a stout apex. The abdomen lacks basal apodemes.

Both Masiripius and Oshaibahus gen. nov. share characters with numerous genera of Opsiina including Afrascius Linnavuori, 1969, Pugla Distant, 1908, Japananus Ball, 1931 (Zahniser \& Dietrich 2013). Both Masiripius and Oshaibahus gen. nov. can be distinguished easily from Afrascius and Japananus by the absence of a marginal carina on the pronotum and the aedeagal shafts separated at the base, and from Pugla by the absence of a marginal carina on the pronotum, with compound eyes narrowly separated forming diamond-shaped crown.

\section{Etymology}

This genus is named in honour of Prof. Alaa Oshaibah, Systematic Entomologist, Department of Zoology, Faculty of Science, Al-Azhar University, Cairo, Egypt. The gender is considered masculine.

\section{Description}

STRUCTURE. External colouration and morphology as in Masiripius, except O. kadiae gen. et sp. nov. that is dusky dorsally. Oshaibahus gen. nov. can be separated from Masiripius by the following characters:

Male Genitalia. Aedeagus with basal process, shafts arising from base but with stout apex.

Female genitalia. Seventh sternite more than $2 \times$ as broad at base as long medially, posterior margin lobe-like, with median V-shaped notch in middle, posterolateral angles conically rounded or acutely rounded. Ovipositor depressed beyond pygofer apex. First valvula medially convex. Second valvula gradually tapered apically with variable serrations on dorsal surface. Numerous macrosetae on pygofer.

\section{Distribution}

Libya (Abdul-Nour 2007), Iraq, Sudan, and KSA (present study). 


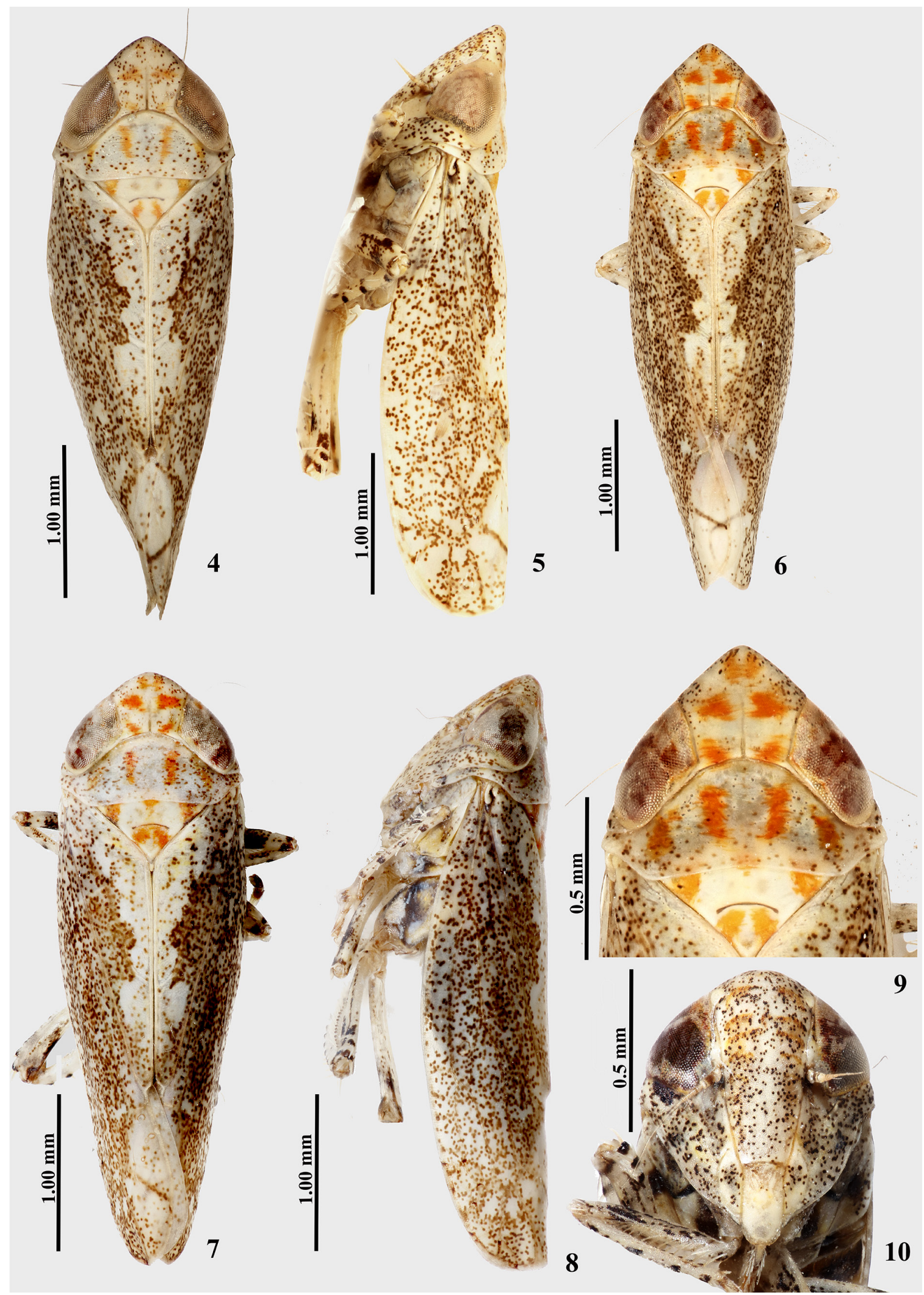

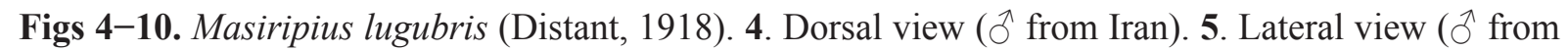

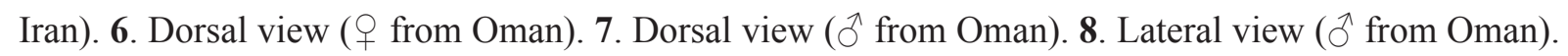
9. Dorsal view of head and thorax ( $q$ from Oman). 10. Face ( $ठ$ from Iran). 


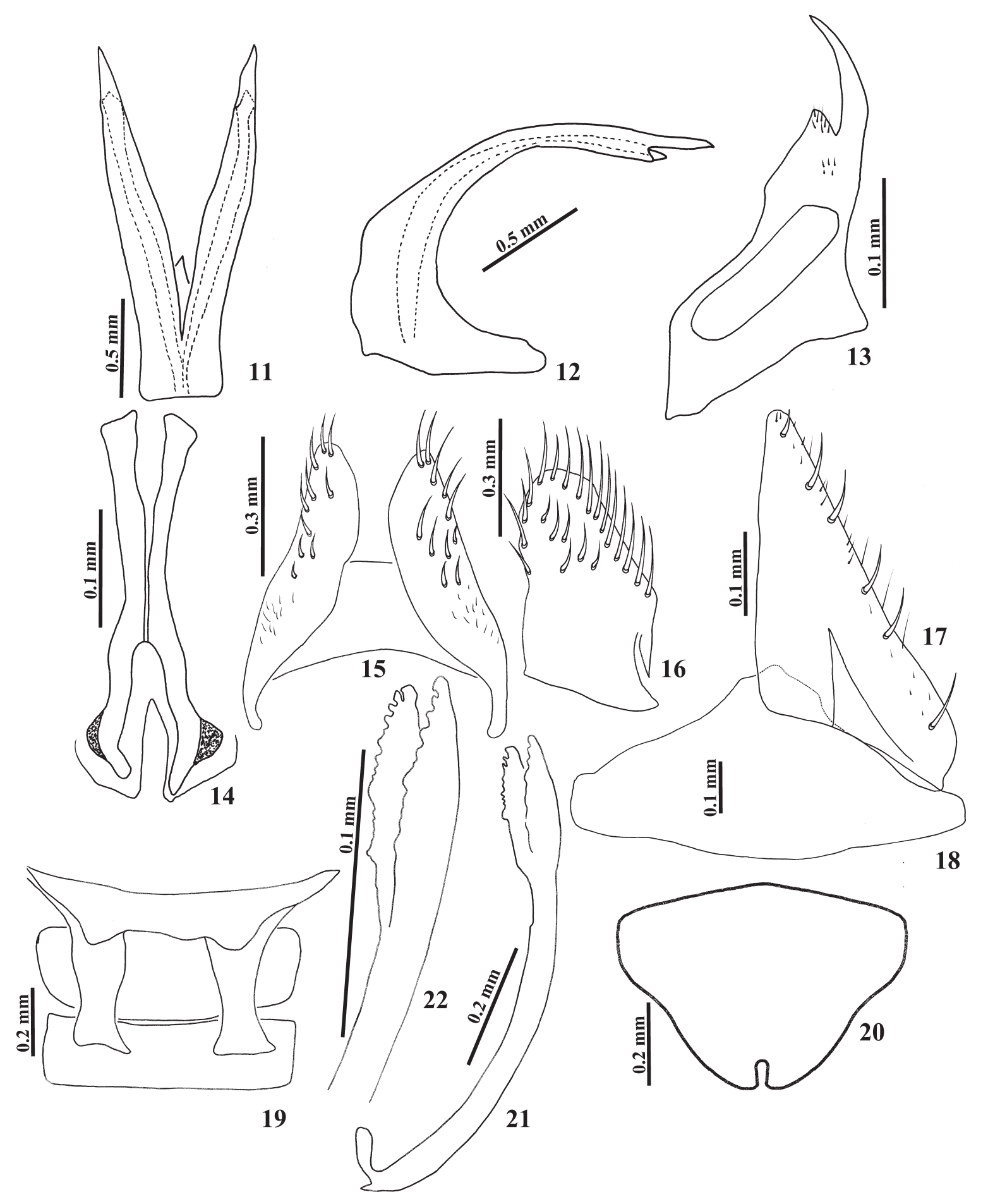

Figs 11-22. Masiripius lugubris (Distant, 1918). 11. Aedeagus dorsal view. 12. Aedeagus lateral view. 13. Style. 14. Connective. 15. Ventral view of pygofer. 16. Lateral view of pygofer. 17. Subgenital plate. 18. Valve. 19. Apodems. 20. 7 $^{\text {th }}$ sternite. 21-22. $q$ ovipositor. 


\section{Key to species of genus Oshaibahus El-Sonbati \& Wilson gen. nov.}

1. Aedeagal process not inflated at the base, the socle length $2 \times$ width, process length equal or longer than length of socle, the tip of process acute and curved preapically, shaft branches arising from base with stout preapex and gradually acute at the apex, at the curve of shafts without external width laterally, with small projection dorsally (Figs 27-28,30)

O. kadiae El-Sonbati \& Wilson gen. et sp. nov.

- Aedeagal process inflated at the base, the socle length equal or subequal the width, the process length equal or shorter than the socle length, the tip of process rounded and not curved preapically, aedeagal shafts arising from base with stout apex, at the curve of shafts with external width laterally, without small projection dorsally (Figs 42-44, 62-63)

2. (1') Aedeagal process length shorter than the socle length, at the curve of shafts with little external width laterally (Figs 42-44)

O. linnavuorii El-Sonbati \& Wilson gen. et sp. nov.

- Adeagal process length equal or longer than the socle length, at the curve of shafts with external width laterally (Figs 62-63) O. zizyphi (Bergevin, 1922) gen. et comb. nov.

Oshaibahus kadiae El-Sonbati \& Wilson gen. et sp. nov. urn:1sid:zoobank.org:act:810DFE69-AFD8-46EE-B3AF-B4BCFF054A9B

Figs 23-36

\section{Etymology}

The patronym honours the co-author's youngest daughter, Kadi Al Dhafer.

\section{Type material}

\section{Holotype}

SUDAN: 1 §̊, Wad Medani, Blue Nile, 11-12 Nov. 1981, R. Linnavuori leg. (AMNH).

\section{Paratype}

SUDAN: 1 , same data as holotype (AMNH).

\section{Description}

Body Length. Male $3.7 \mathrm{~mm}$; female $4.2 \mathrm{~mm}$.

StRUCTURe (Figs 23-26). In addition to generic characters, the specific characters for this species are: clypellar suture convex at apex; lorum as wide as clypellus at base, not widely separated from genal margin; frontoclypeus texture rugose with "netlike" brown colour; crown $2 \times$ as wide as eye.

Male Genitalia (Figs 27-35). Aedeagus with basal process, not inflated at the base, the socle $2 \times$ as wide as long, the process equal or longer than the socle, process tip pointed, curved preapically, aedeagal shafts arising from base with stout preapex and gradually pointed at the apex, at the curve of shafts without extra width laterally, with small projection dorsally.

Female genitalia (Fig. 36). Seventh sternite more than $3 \times$ as broad at base as long medially, posterior margin lobe-like with median $\mathrm{V}$-shape notch in middle, posterolateral angles slightly conically rounded.

\section{Distribution}

Sudan (present study). 


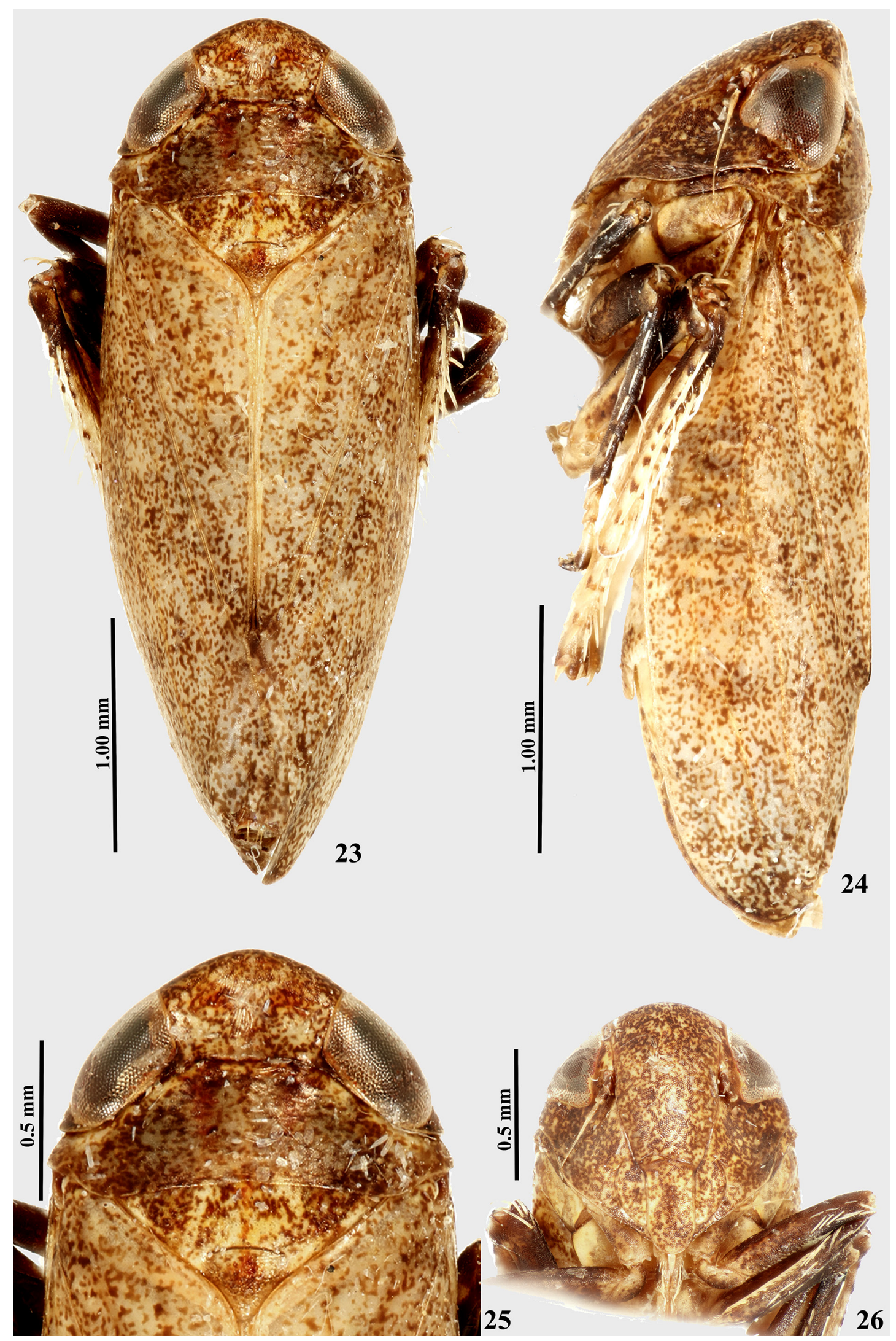

Figs 23-26. Oshaibahus kadiae El-Sonbati \& Wilson gen. et sp. nov. 23. Dorsal view. 24. Lateral view. 25. Dorsal view of head and thorax. 26. Face. 

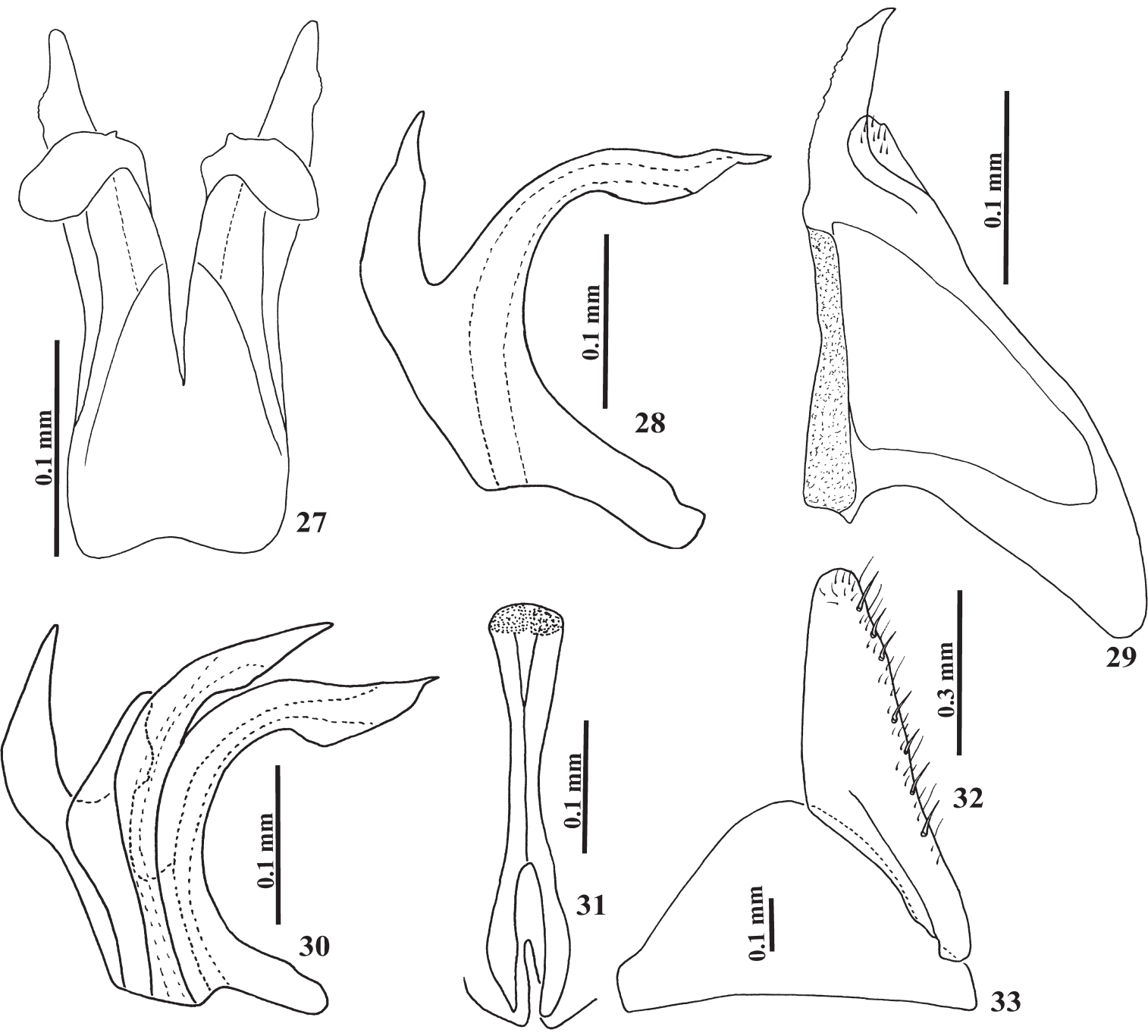

29
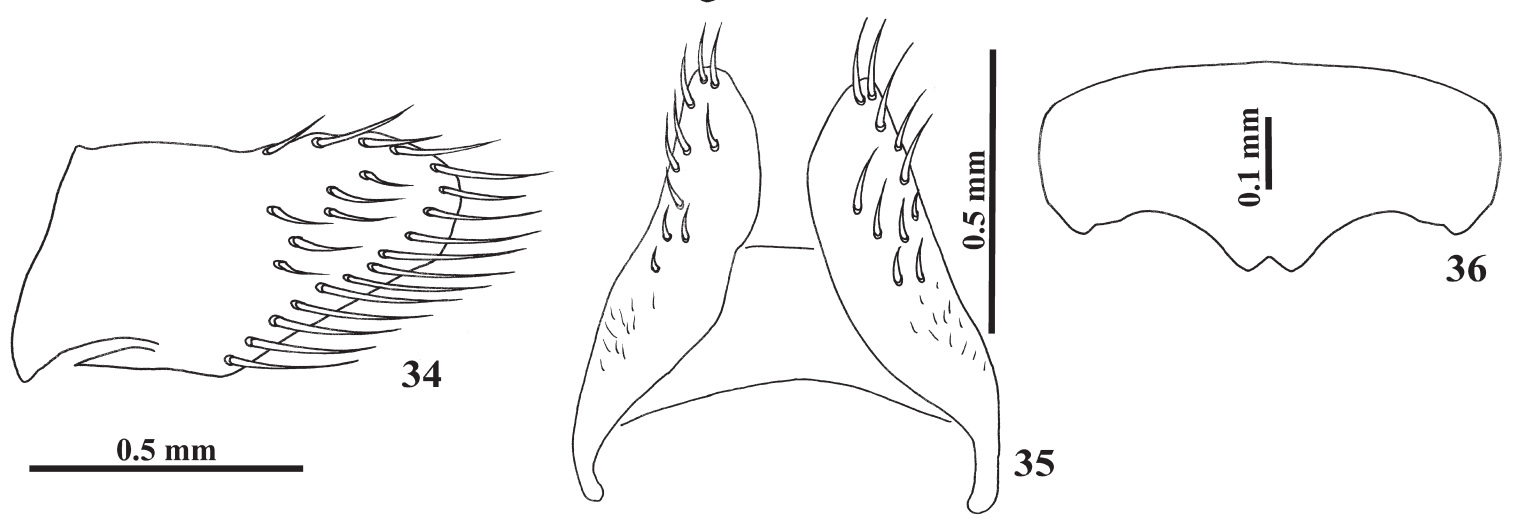

Figs 27-36. Oshaibahus kadiae El-Sonbati \& Wilson gen. et sp. nov. 27. Aedeagus dorsal view. 28, 30. Aedeagus lateral view. 29. Style. 31. Connective. 32. Subgenital plate. 33. Valve. 34. Lateral view of pygofer. 35 . Ventral view of pygofer. $\mathbf{3 6}$. $+7^{\text {th }}$ sternite. 
Oshaibahus linnavuorii El-Sonbati \& Wilson gen. et sp. nov. urn:1sid:zoobank.org:act:4B216514-A3B9-4A5E-B026-4CEF4403CF32

Figs $37-53$

\section{Etymology}

This species is named in honour of the well-known hemipterist Prof. Rauno Linnavuori, who collected the species in Iraq in 1981.

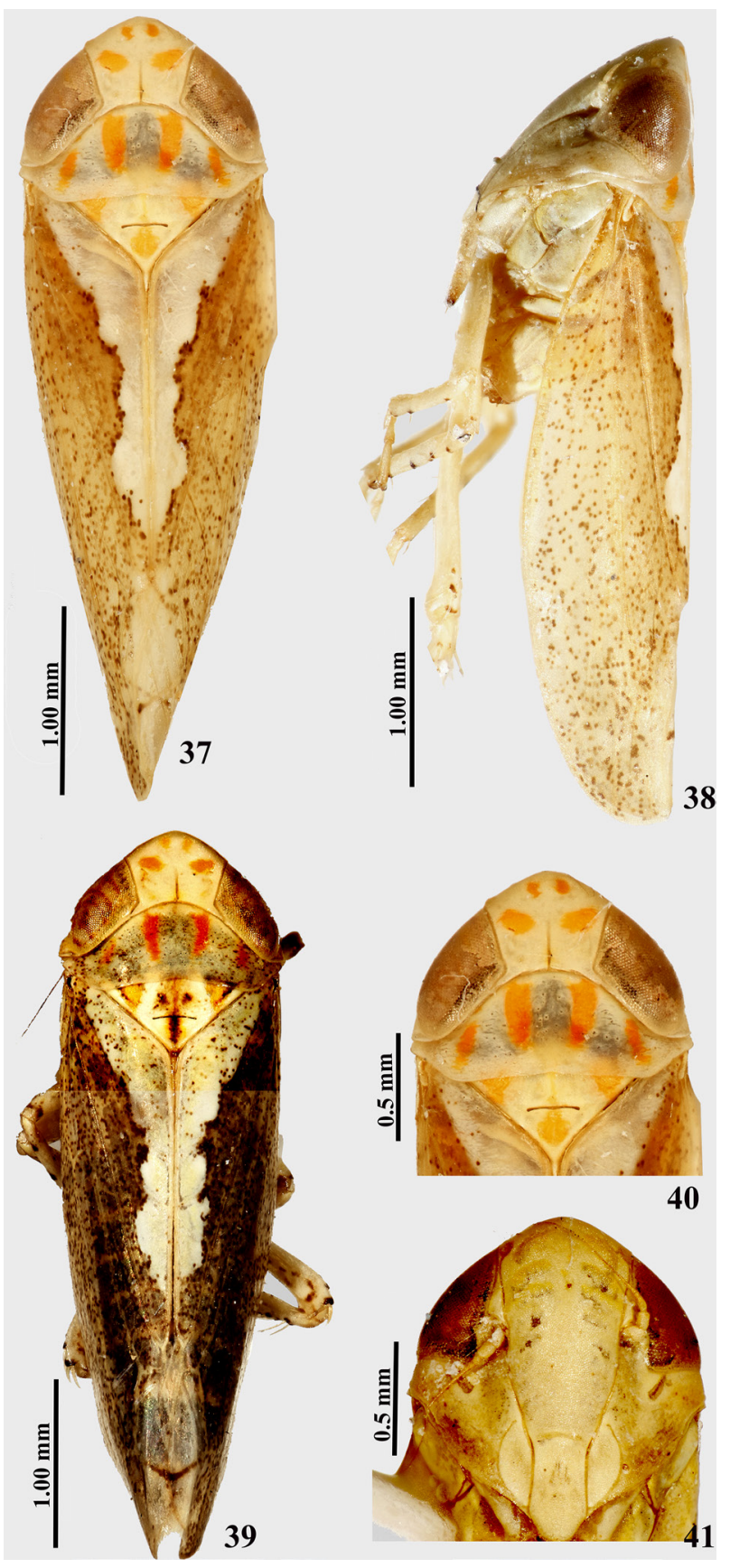

Figs 37-41. Oshaibahus linnavuorii El-Sonbati \& Wilson gen et sp. nov. 37, 39. Dorsal view. 38. Lateral view. 40. Dorsal view of head and thorax. 41. Face. 

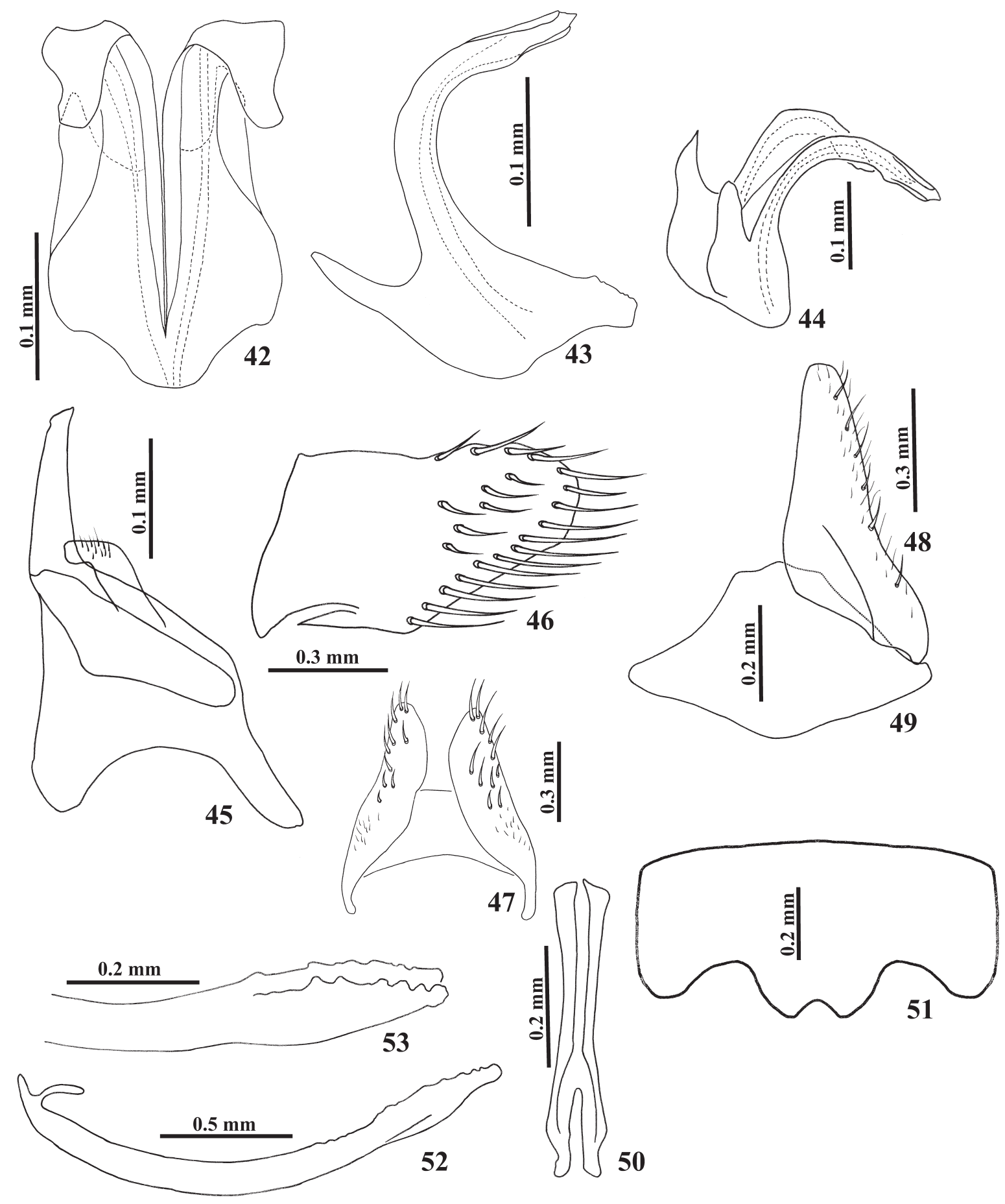

Figs 42-53. Oshaibahus linnavuorii El-Sonbati \& Wilson gen. et sp. nov. 42. Aedeagus dorsal view. 43, 44. Lateral view. 45. Style. 46. Lateral view of pygofer. 47. Ventral view of pygofer. 48. Subgenital plate. 49. Valve. 50. Connective. 51. ( $^{\text {th }}$ sternite. 52-53. $q$ ovipositor. 


\section{Type material}

\section{Holotype}

IRAQ: 1 กै, al-Muthanna, As Salman, [Busaygah], 2 Apr. 1981, R. Linnavuori leg. (AMNH).

\section{Paratypes}

IRAQ: $2 \hat{\partial^{\lambda}}, 1$, same data as holotype; 2 $\propto$, al-Najaf, 24 Jun. 1981, [Khan Ruhabah], R. Linnavuori leg. (AMNH).

\section{Description}

Body LENGTH. Male $4.1 \mathrm{~mm}$; female $4.2 \mathrm{~mm}$.

STRUCTURE (Figs 37-41). In addition to generic characters, the specific characters for this species are: clypellar suture straight, lorum distinctly narrower than clypellus at base, not separated at all from gena margin; frontoclypeus texture shagreen; crown slightly $2 \times$ as wide as eye.

Male Genitalia (Figs 42-50). Aedeagus with basal process, inflated at the base, the socle equal or subequal as wide as long, process shorter than the socle, tip rounded, shafts arising from base with stout apex, laterally expanded near curvature, without dorsal projection.

Female Genitalia (Figs 51-53). Seventh sternite more than $2 \times$ as broad at base as long medially, posterior margin with median lobe-like projection with median V-shape notch, posterolateral angles conically rounded.

\section{Distribution}

Iraq (present study).

Oshaibahus zizyphi (Bergevin, 1922) gen. et comb. nov. Figs $54-72$

Platymetopius zizyphi Bergevin in Bergevin \& Zanon, 1922: 63. — Metcalf 1967: 2241. Masiripius zizyphi-Abdul-Nour 2007: 305.

\section{Differential diagnosis}

Oshaibahus zizyphi gen. et comb. nov. is similar to O. linnavuorii gen. et sp. nov., but can be distinguished easily by the aedeagal process equal or longer than the socle length, and by the curvature of the lateral expansion. This species also resembles $O$. kadiae gen. et sp. nov. but can be easily separated by the socle length equal or subequal to width, by the rounded tip of process, by shaft branches arising from base with stout apex, by the curvature of the shafts and the shape of the lateral expansion, the shafts also lack the dorsal projection.

\section{Material examined}

KSA (all specimens deposited at KSMA and collected by H. Al Dhafer and S. El-Sonbati unless otherwise

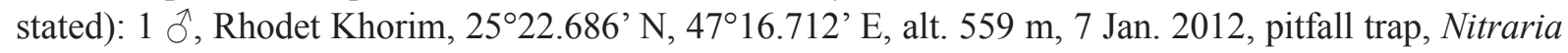
retusa (A); 1 ठ, same locality, 4 Feb. 2012, beating, Nitraria retusa; 1 +, same locality, 6 Mar. 2012,

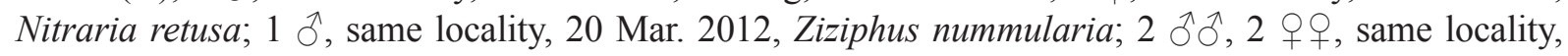
14 Apr. 2012, light trap; 1 , same locality, 28 Apr. 2012, light trap; 5 đô, 5 우, same locality, 28 Apr. 2012, beating, Nitraria retusa; $5 \hat{\jmath} \hat{\partial}, 9$ 우, same locality, 14 May 2012, beating, Nitraria retusa; $2 \hat{\text {, }}$

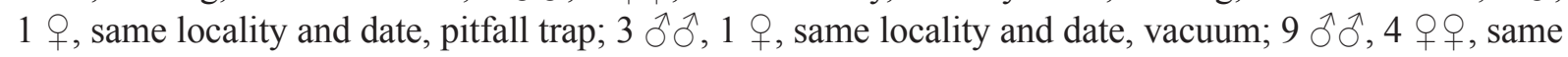

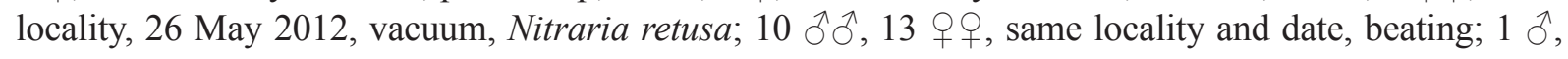



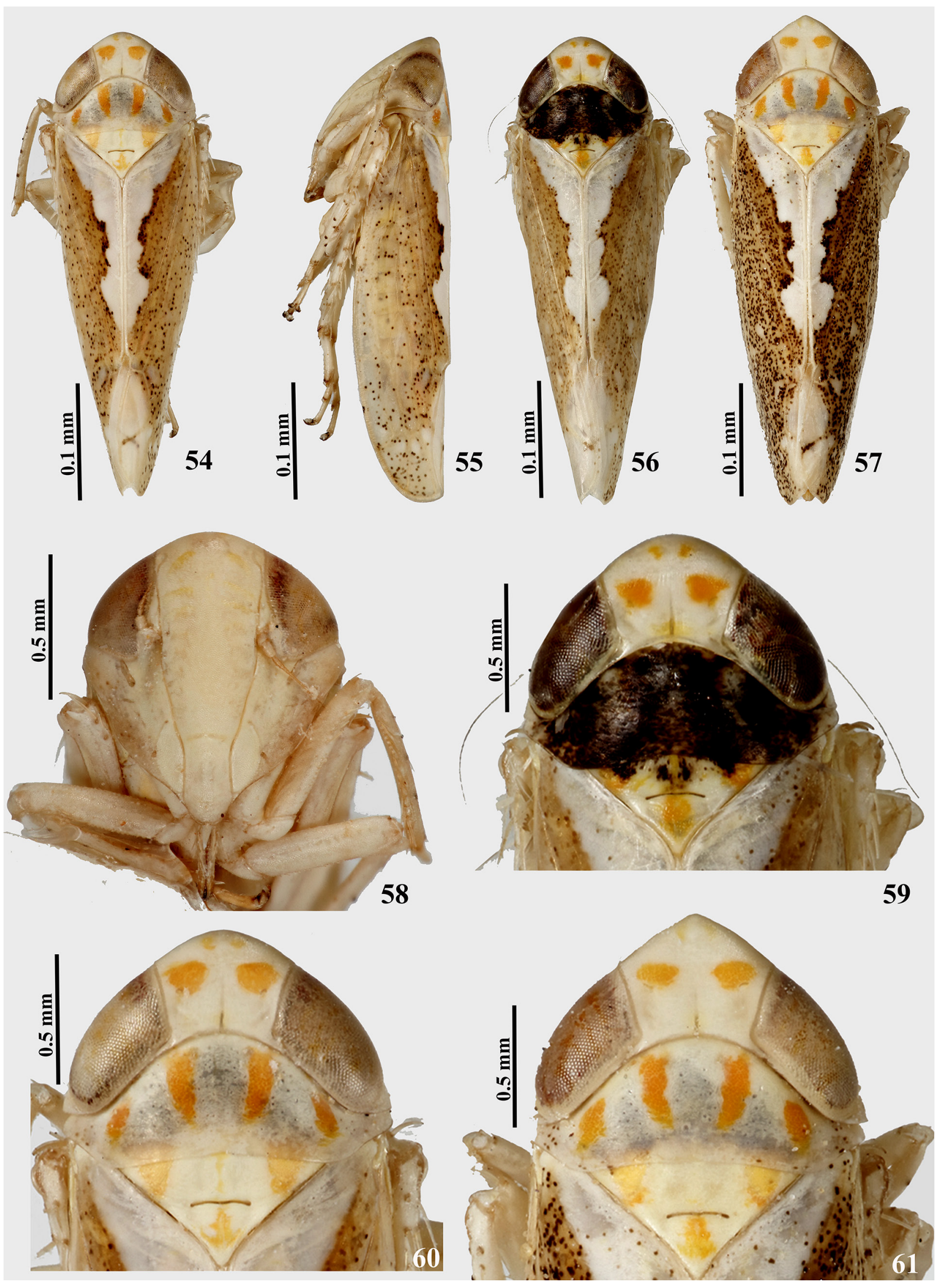

Figs 54-61. Oshaibahus zizyphi (Bergevin, 1922) gen. et comb. nov. 54, 56-57. Dorsal view. 55. Lateral view. 58. Face. 59-61. Dorsal view of head and thorax. 

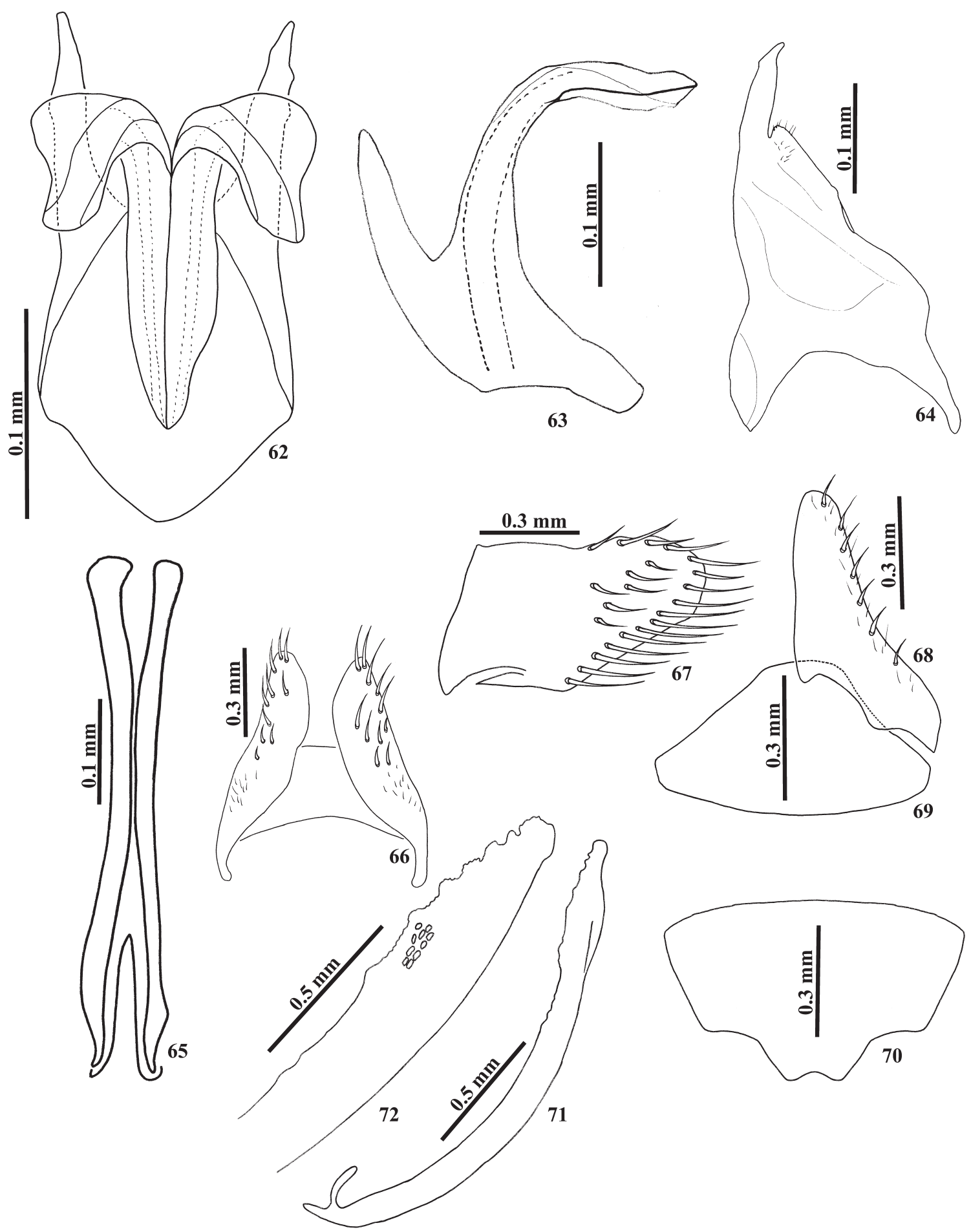

Figs 62-72. Oshaibahus zizyphi (Bergevin, 1922) gen. et comb. nov. 62. Aedeagus dorsal view. 63. Aedeagus lateral view. 64. Style. 65. Connective. 66. Ventral view of pygofer. 67. Lateral view of pygofer. 68. Subgenital plate. 69. Valve. 70. $q 7^{\text {th }}$ sternite. 71-72. $q$ ovipositor. 
same locality, 15 May 2012, light trap; 1 ô, same locality, 2 Jun. 2013, vacuum, Ziziphus nummularia; $1 \hat{\partial}$, same locality and date, beating; 3 우, same locality, 9 Jun. 2012 vacuum, Nitraria retusa; 6 우, same locality and date, beating; $1 \hat{\delta}$, same locality, 10 Jun. 2012, light trap; $2 \hat{\delta} \hat{\partial}$, same locality, 15 Jun.

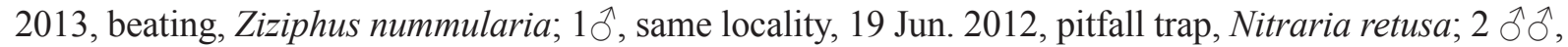

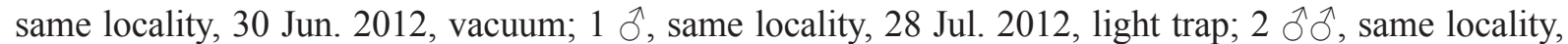

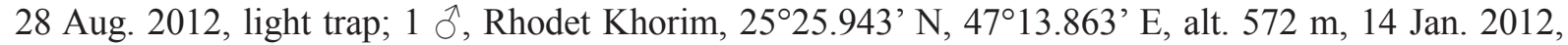
pitfall trap, Lycium shawii (B), H. Al Dhafer \& S. El-Sonbati leg.; 1 ðૈ, 2 우, same locality, 14 Apr. 2012,

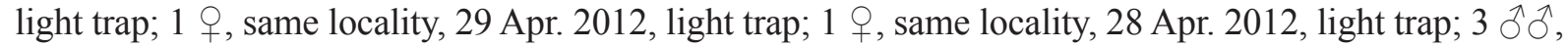
same locality, 27 May 2012 light trap; 1 ô, 1 q, same locality, 11 May 2013, beating, Acacia gerrardii; 1 , same locality, 18 May 2013, vacuum, Ziziphus nummularia; 1 ô, same locality, 9 Jun. 2012, vacuum, Rhazya stricta; 1 ô, same locality and date, Nitraria retusa; 1 ô, 1 q, same locality, 10 Jun. 2012, light trap; 2 ठิ $\widehat{\partial}, 2$ 우, same locality, 2 Jun. 2013, vacuum, Ziziphus nummularia; 1 ô, same locality, 28 Aug. 2012, light trap; $2 \hat{\jmath} \widehat{\partial}$, same locality, 13 Nov. 2011, light trap; $3 \hat{\partial} \widehat{\partial}, 2$ 우우, Muzahimiyah, Al Khararah,

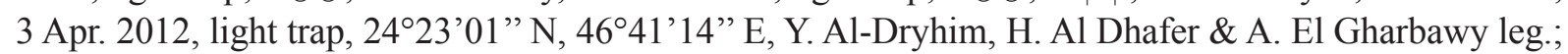

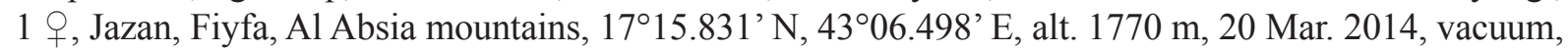
S. El-Sonbati leg.

\section{Description}

StRUCTURE (Figs 54-61). In addition to generic characters, the specific characters for this species are: clypellar suture sinuate apically; lorum distinctly narrower than clypellus at base, not separated at all from gena margin; single fine erect seta on gena distance to lateral frontal suture; frontoclypeus texture shagreen; crown less than $2 \times$ as wide as eye.

Male genitalia (Figs 62-69). Aedeagus with basal process, inflated at the base, the socle equal or subequal as wide as long, process equal or longer than the socle, rounded tip, aedeagal shafts arising from base with stout apex, at the curve of shafts with external width laterally, without small projection dorsally.

Female Genitalia (Figs 70-72). Seventh sternite more than $1.5 \times$ as broad at base as long medially, posterior margin with lobe slightly produced with median $\mathrm{V}$-shape notch in middle, posterolateral angles acutely rounded.

\section{Host plants}

Ziziphus lotus (L.) Lam. (Rhamnaceae).

\section{Distribution}

Algeria (Metcalf 1967), Libya (Abdul-Nour 2007) and KSA (present study).

\section{Discussion}

The genus Masiripius was described based on a misidentified specimen from Iran (Dlabola 1981). Webb \& Godoy (1993) examined the holotype of Mahalana lugubris and designated this taxon as a senior synonym of Zizyphoides punctatus and also of M. zizyphi, which had been misidentified by Dlabola. Webb \& Godoy (1993) also transferred Mahalana lugubris to Masiripius. Viraktamath \& Anantha Murthy (1999) designated M. lugubris as type species of Masiripius. Platymetopius zizyphi is here designated as the type species of Oshaibahus gen. nov.

Despite the comprehensive studies of Cicadellidae carried out by Dlabola $(1979,1980,1987)$ and ElSonabti et al. (2015) in the KSA, as well as Linnavuori (e.g., 1973, 1989) and El-Sonbati et al. (2016) for the Middle East, the Arabian fauna is still relatively poorly known with vast areas unsampled. 
Although our study indicated that Masiripius is closely related to Oshaibahus gen. nov., the geographical distribution of the genera are distinctive. Masiripius apparently dispersed from the Indian subcontinent into the Arabian Peninsula and is known from Oman and Qatar. Collections of leafhoppers from the southwestern and central provinces of the KSA have not included this genus. The distribution of species of Oshaibahus appears to include Palaearctic and Afrotropical elements, with O. zizyphi gen. et comb. nov. widely distributed between Asia and Africa.

The host plants of Oshaibahus zizyphi gen. et comb. nov. are species of Ziziphus; Z. lotus (L.) Lam. and Z. mauritiana Lam. (Rhamnaceae) (Bergevin \& Zanon 1922; Bhattacharyna \& Harb 1973; Viraktamath \& Anantha Murthy 1999). Ziziphus species form small trees and are utilized as an important source of vegetable oil and protein from the seeds, whereas fruits and leaves are also utilized for medicinal purposes (Al-Khamis et al. 2012; Chouaibi et al. 2012; Alqarni 2015). In this study, specimens of Oshaibahus gen. nov. were collected at Muzahimiyah, Al Khararah and Rhodet Khorim from four species of plants: Ziziphus nummularia (Burm. f.) Wright \& Arn. (family Rhamnaceae), Acacia gerrardii Benth. (family Leguminosae-Mimosoideae), Nitraria retusa (Forssk.) Asch. (family Nitrariaceae), and Lycium shawii Roem \& Schult. (family Solanaceae).

\section{Acknowledgements}

The authors are grateful to John Deeming (NMWC) for his valuable suggestions, to Chandra Viraktamath for his permission to use some of his photos (GKVK), to Michael Webb for helping to examine specimens (BMNH), to James Turner (NMWC) for help in photographing specimens, to Boris Kondratieff (Colorado State University), James Zahniser (USDA-APHIS) and Chloe Chester (MNHN) for reading and improving the manuscript. The authors extend their appreciation to the Deanship of Scientific Research at King Saud University for funding this work through research group No. (RG1437-009).

\section{References}

Abdul-Nour H. 2007. Cicadellidae de Libye: description d'espèces nouvelles ou peu connues (Hemiptera, Cicadomorpha). Nouvelle Revue d'Entomologie (N.S.) 23 (4): 301-308.

Al-Khamis H.H., Al-Hemaid F.M. \& Ibrahim A.S.S. 2012. Diversity of perennial plants at Ibex Reserve in Saudi Arabia. Journal of Animal and Plant Sciences 22 (2): 484-492.

Alqarni A.S. 2015. Honeybee foraging, nectar secretion, and honey potential of wild Jujube trees, Ziziphus nummularia. Neotropical Entomology 44 (3): 232-241. https://doi.org/10.1007/s13744-015$\underline{0279-4}$

Bergevin E.D. \& Zanon D.V. 1922. Danni alla Vite in Cirenaica e Tripolitania dovuti ad un nuovo Omottero (Chlorita Lybica sp. nov.). L'Agricoltura Coloniale 16: 58-64.

Bhattacharyna A.N. \& Harb M. 1973. Dried citrus pulp as a grain replacement for Awasi lambs. Journal of Animal Science 36 (6): 1175-1180. https://doi.org/10.2527/jas1973.3661175x

Chouaibi M., Mahfoudhi N., Rezig L., Donsì F., Ferrari G. \& Hamdi S. 2012. Nutritional composition of Zizyphus lotus L. seeds. Journal of the Science of Food and Agriculture 92 (6): 1171-1177. https:// doi.org/10.1002/jsfa.4659

Dietrich C.H. 2005. Keys to the families of Cicadomorpha and subfamilies and tribes of Cicadellidae (Hemiptera: Auchenorrhyncha). Florida Entomologist 88(4): 502-517. https://doi.org/10.1653/00154040(2005)88[502:KTTFOC]2.0.CO;2

Distant, W.L. 1918. The Fauna of British India, including Ceylon and Burma. Rhynchota. Vol. VII. Homoptera: Appendix. Heteroptera: Addenda. Taylor \& Francis, London. 
EL-SONBATI S.A. et al., A new leafhopper genus and two new species

Dlabola J. 1979. Insects of Saudi Arabia. Homoptera. Fauna of Saudi Arabia 1: 115-139.

Dlabola J. 1980. Insects of Saudi Arabia. Homoptera: Auchenorrhyncha (Part 2). Fauna of Saudi Arabia 2: 74-94.

Dlabola J. 1981. Ergebnisse der tschechoslowakisch-iranischen entomologischen Expeditionen nach dem Iran (1970 und 1973). Acta Entomologica Musei Nationalis Pragae 40: 127-311.

Dlabola J. 1987. Neue Zikadenarten von Saudi Arabien (Homoptera: Auchenorrhyncha). 3. Teil. Annotationes Zoologicae et Botanicae 177: 1-11.

El-Sonbati S.A., Wilson M.R. \& Al Dhafer H.M. 2015. A new species of the leafhopper genus Naevus Knight, 1970 (Hemiptera: Cicadellidae: Deltocephalinae: Opsiini), from Saudi Arabia. Zootaxa 4059(2): 393. https://doi.org/10.11646/zootaxa.4059.2.10

El-Sonbati S.A., Wilson M.R. \& Al Dhafer H.M. 2016. Paraorosius, a new genus of leafhopper (Hemiptera: Cicadellidae: Deltocephalinae: Opsiini), with description of a new species from the Middle East. Zootaxa 4150(5): 581. https://doi.org/10.11646/zootaxa.4150.5.5

Fletcher J. \& Wayadande A. 2002. Fastidious vascular-colonizing bacteria. The Plant Health Instructor. APS, U.S.A. https://doi.org/10.1094/PHI-I-2002-1218-02

Hamilton K.G.A. \& Whitcomb R.F. 2010. Leafhoppers (Homoptera: Cicadellidae): a major family adapted to grassland habitats. Arthropods of Canadian Grasslands 1: 169-197. https://doi. org/10.3752/9780968932148.ch8

Hollier J.A., Maczey N., Masters G.J. \& Mortimer S.R. 2005. Grassland leafhoppers (Hemiptera: Auchenorrhyncha) as indicators of habitat condition - a comparison of between-site and between-year differences in assemblage composition. Journal of Insect Conservation 9 (4): 299-307. https://doi. org/10.1007/s10841-005-8821-z

Linnavuori R. 1973. Hemiptera of the Sudan, with remarks on some species of the adjacent countries. 2. Homoptera auchenorrhyncha [sic]: Cicadidae, Cercopidae, Machaerotidae, Membracidae and Fulgoroidea. Notulae Entomologicae 53: 65-137.

Linnavuori R.E. 1989. New taxa of Heteroptera and Auchenorrhyncha from the Middle East and the Ethiopian Region. Annales Entomologici Fennici 55: 1-9.

MetcalfZ.P. 1967. General Catalogue of the Homoptera. Fascicle VI. Cicadelloidea. Part 10. Euscelidae. Section III. U.S. Department of Agriculture, Agriculture Research Service, Washington D.C.

Munyaneza J.E., Crosslin J.M., Upton J.E. \& Buchman J.L. 2008. Incidence of the beet leafhoppertransmitted virescence agent phytoplasma in local populations of the beet leafhopper, Circulifer tenellus, in Washington State. Journal of Insect Science 10 (18): 1-10. https://doi.org/10.1673\%2F031.010.1801

Nielson M.W. 1968. The leafhopper vectors of phytopathogenic viruses (Homoptera, Cicadellidae): taxonomy, biology, and virus transmission. Technical bulletin 1382. U.S. Department of Agriculture, Washington D.C.

Nielson M.W. \& Knight W.J. 2000. Distribution patterns and possible origin of leafhopper (Homoptera, Cicadellidae). Revista Brasileira de Zoologia 17 (1): 81-156. https://doi.org/10.1590/S0101$\underline{81752000000100010}$

Oman P.W., Knight W. J. \& Nielson M.W. 1990. Leafhoppers (Cicadellidae): A bibliography, generic check-list and index to the world literature 1956-1985. C.A.B. International Institute of Entomology, Wallingford, Oxon, U.K.

Rao K.R. 1967. On a new species of Zizyphoides Distant (Homoptera: Jassidae) from India. Oriental Insects 1(3-4): 239-241. 
Viraktamath C.A. \& Anantha Murthy H.V. 1999. A revision of the leafhopper tribe Scaphytopiini from India and Nepal (Insecta, Hemiptera, Cicadellidae, Deltocephalinae). Senckenbergiana biologica 79: $39-56$.

Webb M.D. 1981. The Asian, Australasian and Pacific Paraboloponinae (Homoptera: Cicadellidae). Bulletin of the British Museum (Natural History) (Entomology) 43(2): 39-76.

Webb M.D. \& Godoy C. 1993. Review of the leafhopper tribe Scaphytopiini (Homoptera: Cicadellidae: Deltocephalinae) with a key to genera. Journal of Natural History 27 (2): 423-427. https://doi. org/10.1080/00222939300770181

Weintraub P.G. 2007. Insect vectors of phytoplasmas and their control - an update. Bulletin of Insectology 60 (2): 169-173.

Wu D., Wei C. \& Bin X. \& YaLin Z. 2010. A new genus and species of Old World Opsiini (Hemiptera: Cicadellidae: Deltocephalinae), with a key to genera and species checklist for the tribe. Zootaxa 2607: $55-68$

Zahniser J.N. \& Dietrich C.H. 2008. Phylogeny of the leafhopper subfamily Deltocephalinae (Insecta: Auchenorrhyncha: Cicadellidae) and related subfamilies based on morphology. Systematics and Biodiversity 6 (1): 1-24. https://doi.org/10.1017/S1477200007002617

Zahniser J.N. \& Dietrich C.H. 2013. A review of the tribes of Deltocephalinae (Hemiptera: Auchenorrhyncha: Cicadellidae). European Journal of Taxonomy 45: 1-211. https://doi.org/10.5852/ ejt.2013.45

Manuscript received: 17 February 2016

Manuscript accepted: 24 August 2016

Published on: 6 April 2017

Topic editor: Gavin Broad

Desk editors: Chloe Chester \& Laurence Bénichou

Printed versions of all papers are also deposited in the libraries of the institutes that are members of the EJT consortium: Muséum national d'Histoire naturelle, Paris, France; Botanic Garden Meise, Belgium; Royal Museum for Central Africa, Tervuren, Belgium; Natural History Museum, London, United Kingdom; Royal Belgian Institute of Natural Sciences, Brussels, Belgium; Natural History Museum of Denmark, Copenhagen, Denmark; Naturalis Biodiversity Center, Leiden, the Netherlands. 